\title{
ANALISIS MINAT MENABUNG NASABAH PT. BPR PRIMA MULTI MAKMUR
}

\author{
Djemuni ${ }^{1}$, Mochammad Faisal Fadli ${ }^{*}$ \\ 1,2 Akademi Sekretari Manajemen Indonesia Pontianak \\ *Corresponding : faisalsw88@gmail.com
}

\section{CHRONICLE}

Article History:

Received December 5, 2020

Accepted May 18, 2021

\section{Keywords :}

savings interest, customers, PT. BPR

Prima Multi Makmur

\section{ABSTRACT}

This study was conducted to determine the effect of customer interest in deciding to save at PT. BPR Prima Multi Makmur and to find out which factors are the most dominant in determining customer interest in deciding to save at PT. BPR Prima Multi Makmur. This research was conducted using a quantitative descriptive method, namely by analyzing respondents' answers with questionnaires that had been distributed. Then the results of these answers will be grouped based on existing criteria and the results of each statement answer are added up in the form of percentages then analyzed and draw conclusions from the research conducted. The results of the analysis using a Likert scale on thirty questionnaires for respondents' responses that have been distributed, the researchers set the indicator to get an average value of 3.07 in the "Neutral" category.

\section{Latar Belakang :}

Sektor perbankan saat ini masih berperan sebagai penggerak utama pembangunan ekonomi di Indonesia artinya perbankan tetap menjadi permainan utama di sistem keuangan nasional. Lihat saja dari segi asset industri ini menguasai lebih dari $80 \%$ asset seluruh sektor keuangan, karena itulah industri perbankan akhirnya menjadi begitu disorot, perkembangan yang dicapai industri perbankan terutama pada produk dana belakangan ini masih lumayan pesat, Karena dana merupakan produk unggulan semua bank.

Saat ini persaingan di sektor perbankan sudah sangat ketat, setiap bank berlomba-lomba untuk meningkatkan dananya. Hal ini sangat menguntungkan bagi calon nasabah yang ingin menyimpan dananya, mereka bisa memilih bank mana yang bisa dipercaya untuk menyimpan dana. Hal ini juga dipengaruhi oleh beberapa faktor seperti: pendapatan, pendidikan, umur, pekerjaan, jenis kelamin dan jumlah anggota keluarga. Nasabah yang menyimpan dananya pada sebuah bank memiliki latar belakang yang berbeda-beda, untuk itu diperlukan keterampilan khusus yang harus dimiliki oleh pegawai bank, sehingga nasabah merasa yakin akan bank yang dipilihnya.

Satu tahun terakhir ini, beberapa sektor usaha terdampak oleh wabah pandemi virus korona (Covid-19), termasuk di dalamnya adalah sektor perbankan. Oleh karena itu, agar sektor perbankan dapat tetap eksis di tengah pandemi virus korona, maka perbankan harus melakukan mitigasi risiko secara cermat, serta menggunakan strategi kreatif menghadapi kondisi yang serba tidak menentu saat ini.

Wabah pandemi Covid-19 memaksa individu/kelompok/institusi/negara, untuk mengubah pola hidup dan perilakunya selama ini. Jika individu/kelompok/institusi/negara, tidak melakukan perubahan, maka dengan sendirinya perubahan tersebut yang akan 
melindasnya, tanpa terkecuali di dalamnya sektor usaha perbankan. Jika bank ingin keluar dari kondisi keterpurukan, maka sepatutnya bank tidak dapat menggunakan metode atau cara-cara lama dalam memasarkan layanan produk dan jasanya. Korona telah mendekonstruksi tatanan/sistem perbankan yang sudah berjalan selama ini.

Sekarang banyak berkembang BPR (Bank Perkreditan Rakyat) dimasyarakat yang bersaing secara sehat untuk memberikan beberapa kemudahan masyarakat dalam simpanan maupun pinjaman. Dalam memberikan jasanya perusahaan mempertimbangkan beberapa aspek diantaranya: Pelayanan merupakan hal yang harus diutamakan dalam perusahaan jasa karena dengan pelayanan yang baik akan menarik untuk menggunakan jasa tersebut. Produk tabungan yaitu salah satu produk yang dimiliki perbankan yang memiliki atau mempunyai beberapa pilihan produk tabungan untuk dipilih nasabah sesuai dengan kebutuhan masing-masing nasabah.Lokasi merupakan tempat berdirinya suatu perusahaan untuk melakukan kegiatan operasi setiap harinya. Keputusan menabung merupakan keputusan yang diambil nasabah untuk menyimpan uang untuk kebutuhan yang akan datang.

Pertumbuhan yang tinggi dialami oleh bank umum maupun BPR sehingga tingkat persaingan BPR saat ini kian tinggi, terlihat dari banyaknya jumlah BPR yang tersebar saat ini di Indonesia telah mencapai angka 1.593 (seribu lima ratus sembilan puluh tiga) unit, di Kalimantan Barat sendiri jumlah BPR mencapai 20 (dua puluh) unit dan khususnya di Pontianak BPR yang masih beroperasi ada 15 (lima belas) unit (Perbarindo, 2020).

Pada PT. BPR Prima Multi Makmur kegiatan terbatas hanya pada menghimpun dana dalam bentuk tabungan dan deposito yang kemudian dana tersebut di salurkan kembali dalam bentuk kredit. Pada tabungan terdapat tiga jenis yaitu tabungan premium untuk perusahaan atau yayasan, tabungan prima untuk perorangan, dan tabungan ananda untuk anak-anak. Sedangkan kredit yang ditawarkan ada lima jenis yaitu (KMG) kredit multi guna, (KKB) kredit kendaraan bermotor, (KPR) kredit kepemilikan rumah, (KI) kredit investasi dan (KMK) kredit modal kerja.

Di bawah ini terdapat uraian data jumlah nasabah pada PT BPR Prima Multi Makmur selama 5 tahun terakhir dengan tujuan untuk mengetahui minat nasabah menabung di PT BPR Prima Multi Makmur.

Tabel 1. Jumlah Nasabah PT. BPR Prima Multi Makmur Tahun 2016 - 2020

\begin{tabular}{|c|c|c|}
\hline Tahun & Jumlah Nasabah (Orang) & Perkembangan (\%) \\
\hline 2016 & 15.931 & - \\
2017 & 14.333 & -10.04 \\
2018 & 13.762 & -3.99 \\
2019 & 16.124 & 17.16 \\
2020 & 18.569 & 15.16 \\
\hline
\end{tabular}

Sumber : PT BPR Prima Multi Makmur, 2020

Berdasarkan Tabel 1 di atas dapat diketahui bahwa terjadi fluktuatif persentase jumlah nasabah pada PT BPR Prima Multi Makmur dari tahun 2016 sampai tahun 2020, tahun 2016 jumlah nasabah 15.931 orang, pada tahun 2017 jumlah nasabah turun sebesar 1.598 orang menjadi 14.333 orang atau persentase penurunan sebesar 10.04 persen. Pada tahun 2018 jumlah nasabah kembali mengalami penurunan sebesar 571 orang sehingga menjadi 13.762 orang atau persentase penurunan sebesar 3.99 persen. Pada tahun 2019 jumlah nasabah mengalami kenaikan sebesar 2.362 orang menjadi 16.124 orang atau persentase kenaikan sebesar 17.16 persen. Pada tahun 2020 jumlah nasabah kembali mengalami kenaikan sebanyak 2.445 orang menjadi 18.569 orang dengan persentase kenaikan sebesar 15.16 persen. 
Tabel 2. Jumlah Saldo Tabungan PT. BPR Prima Multi Makmur Tahun 2016 - 2020

\begin{tabular}{|c|c|c|}
\hline Tahun & Total Saldo Tabungan (Jutaan) & Perkembangan (\%) \\
\hline 2016 & 97.019 & - \\
2017 & 122.048 & 25.79 \\
2018 & 100.042 & -18.03 \\
2019 & 102.983 & 2.94 \\
2020 & 103.891 & 0.88 \\
\hline
\end{tabular}

Sumber : Data Olahan, PT BPR Prima Multi Makmur, 2020

Berdasarkan Tabel 2 di atas dapat diketahui bahwa persentase total saldo tabungan pada PT BPR Prima Multi Makmur pada tahun 2016 sebesar Rp 97.019,- juta, pada tahun 2017 total saldo tabungan naik sebesar Rp 25.029,- juta menjadi Rp 122.048,- juta atau persentase kenaikan sebesar 25.79 persen. Pada tahun 2018 total tabungan mengalami penurunan sebesar Rp 22.006,- juta menjadi Rp 100.042,- juta atau persentase penurunan sebesar 18.03 persen. Pada tahun 2019 total tabungan mengalami kenaikan sebesar Rp 2.941,- juta menjadi Rp 102.983,- juta persentase kenaikan sebesar 2.94 persen. Pada tahun 2020 total tabungan kembali mengalami kenaikan sebesar Rp 908,- juta menjadi Rp 103.891,- juta atau persentase mengalami kenaikan sebesar 0.88 persen.

\section{Tinjauan Pustaka}

1. Pengertian Minat

Minat (intersest) berarti kecenderungan atau kegairahan yang tinggi atau keinginan yang besar terhadap sesuatu. Minat dalam kamus besar bahasa Indonesia diartikan sebagai "sebuah kecenderungan hati yang tinggi terhadap suatu gairah atau keinginan". Minat merupakan keinginan yang timbul dari diri sendiri tanpa ada paksaan dari orang lain untuk mencapai suatu tujuan tertentu. Minat adalah rasa suka (senang) dari rasa tertarik pada suatu objek atau aktivitas tanpa ada yang menyuruh atau biasanya ada kecenderungan untuk mencari objek yang disenangi tersebut. Minat lebih dikenal sebagai keputusan pemakaian atau pembelian jasa/produk tertentu. Keputusan pembelian merupakan suatu proses pengambilan keputusan atas pembelian yang mencakup penentuan apa yang akan dibeli atau tidak melakukan pembelian dan keputusan tersebut diperoleh dari kegiatan-kegiatan sebelumnya yaitu kebutuhan dan dana yang dimiliki.

\section{Pengertian Minat Menabung}

Berdasarkan konsep pemasaran maka bagi manajemen pemasaran memahami perilaku pembeli merupakan tugas yang sangat penting. Pasar nasabah adalah terdiri dari semua individu dan rumah tangga yang membeli atau memperoleh barang atau jasa untuk konsumsi pribadi. Minat menabung menurut Kotler (2011:14) menyatakan Minat menabung adalah tindakan dari nasabah untuk mau membeli atau tidak terhadap produk. Dari berbagai faktor yang mempengaruhi nasabah dalam melakukan pembelian suatu produk atau jasa, biasanya nasabah selalu mempertimbangkan kualitas, inflasi dan produk yang sudah di kenal oleh masyarakat sebelum nasabah memutuskan untuk membeli.

Berikut ini Peter dan Olson (2013) juga menyatakan tentang Minat menabung, yakni perilaku nasabah sendiri merupakan tindakan-tindakan individu yang secara langsung terlibat dalam usaha memperoleh, menggunakan produk dan jasa, termasuk proses pengembalian keputusan yang mengakui dan mengikuti tindakan-tindakan tersebut. Selanjutnya Kurnia (2013) Minat menabung merupakan keputusan nasabah untuk membeli suatu produk setelah sebelumnya memikirkan tentang layak tidaknya membeli produk itu dengan 
mempertimbangkan informasi-informasi yang ia ketahui dengan realitas tentang produk itu setelah ia menyaksikannya. Dari beberapa pendapat di atas dapat disimpulkan bahwa Minat menabung merupakan suatu keputusan seseorang dimana dia memilih salah satu dari beberapa alternatif pilihan.

Secara umum nasabah mengikuti suatu proses atau tahapan dalam pengambilan keputusan. Ada enam tahap dalam proses Minat menabung yaitu menganalisa keinginan dan kebutuhan, menilai sumber-sumber, menetapkan tujuan pembelian, mengidentifikasi alternatif pembelian, keputusan pembeli dan perilaku sesudah pembelian.

Kotler (2011) mengemukakan ada lima tahap proses Minat menabung yaitu :

a. Pengenalan Masalah

Proses membeli nasabah dimulai karena adanya suatu masalah atau suatu kebutuhan dan kebutuhan tersebut dapat digerakkan oleh rangsangan dari luar maupun dalam pembeli. Dari kebutuhan normal seseorang, yaitu rasa lapar atau dahaga akan meningkatkan hingga suatu tingkat tertentu dan merubah menjadi dorongan, yang biasanya ditimbulkan dari rangsangan internal. Dan kebutuhan yang didapat dari rangsangan eksternal misalnya seseorang yang membeli mobil disebabkan karena melihat mobil baru tetangganya.

b. Pencarian Informasi.

Tahap kedua dari proses ini sangat berkaitan dengan pencarian informasi. Untuk memenuhi kebutuhan yang diinginkan karena pencarian informasi bersifat aktif harus dapat berubah kunjungan terhadap beberapa toko untuk membuat perbandingan inflasi dan suku bunga. Sedangkan informasi pasif, mungkin hanya membaca suatu pengiklanan di majalah atau surat kabar tanpa mempunyai tujuan khusus alam tujuannya tentang gambaran yang diinginkan.

c. Evaluasi Alternatif.

Tahap evaluasi alternatif terjadi setelah nasabah menetapkan tujuan pembelian kemudian mengadakan seleksi terhadap alternatif pembelian berdasarkan tujuan pembeliannya. Tujuan pembelian masing masing nasabah tidak selalu sama, tergantung pada jenis produk dan kebutuhannya. Ada nasabah yang mempunyai tujuan pembelian untuk meningkatkan prestasi, ada yang hanya sekedar ingin memenuhi kebutuhan jangka pendek, ada juga yang ingin meningkatkan pengetahuan. Setelah tujuan pembelian ditetapkan, nasabah perlu mengidentifikasikan alternatif- alternatif pembeliannya. Pengidentifikasikan alternatif tersebut tidak dapat terpisah dari pengaruh sumber sumber yang dimiliki maupun resiko keliru dalam pemilihan. Atas dasar tujuan pembelian, alternatif-alternatif pembelian yang telah diidentifikasikan dinilai dan diseleksi menjadi alternatif pembelian yang dapat memenuhi dan memuaskan kebutuhan serta keinginannya.

d. Minat menabung.

Keputusan untuk membeli disini merupakan proses dalam pembelian yang nyata. Jadi setelah tahap-tahap dimuka dilakukan, maka nasabah harus mengambil keputusan apakah membeli atau tidak. Bila nasabah memutuskan untuk membeli, nasabah akan menjumpai serangkaian keputusan yang harus diambil menyangkut produk, inflasi, penjual, waktu pembelian dan setiap perusahaan dapat mengusahakan untuk menyederhanakan pengambilan keputusan yang akan dilakukan oleh para nasabah. Oleh karena itu, orang yang menemui kesulitan dalam membuat Minat menabung. Perusahaan perlu mengetahui berapa jawaban-jawaban atas pertanyaan-pertanyaan menyangkut perilaku nasabah dalam Minat menabungnya.

e. Perilaku Pasca Pembelian.

Setelah melakukan pembelian, nasabah akan mengalami beberapa tingkat kepuasan atau ketidakpuasan. Nasabah juga akan melakukan beberapa kegiatan, seperti kepuasan 
pasca pembelian dan tindakan pasca pembelian. Dilihat dari tahap-tahap dalam proses Minat menabung tersebut, seseorang nasabah yang merasa puas cendrung akan mengatakan hal-hal yang baik. Sebaliknya nasabah yang merasa tidak puas akan berusaha mengurangi ketidaksesuaian tersebut. Untuk mengatasi ketidakpuasan tersebut nasabah dapat melakukan tindakan-tindakan sebagai berikut:

a) Mengambil tindakan. Baik dilakukan secar individu maupun yang dilakukan secara bersama-sama.

b) Tidak mengambil tindakan sama sekali.

3. Faktor-faktor yang mempengaruhi minat masyarakat menabung

Menurut Tjiptono (2010), pengetahuan, pelayanan dan lokasi merupakan faktor yang penting dalam usaha menarik minat konsumen atau pelanggan. Faktor-faktor yang mempengaruhi kurangnya minat masyarakat menabung yaitu :

a. Pengaruh Pengetahuan Terhadap Minat Menabung

Notoadmodjo (2003) dalam Wawan dan Dewi (2010) menyatakan bahwa :Pengetahuan merupakan hasil dari tahu dan ini terjadi setelah orang melakukan pengindraan terhadap suatu objek tertentu. Pengindraan terjadi melalui pancaindra manusia, yakni indra penglihatan, pendengaran, penciuman, rasa, dan raba dengan sendiri. Sebagian besar pengetahuan manusia diperoleh melalui mata dan telinga. Pengetahuan masyarakat adalah semua informasi yang dimiliki masyarakat mengenai berbagai macam produk dan jasa perbankan, serta pengetahuan lainnya yang terkait dengan perbankan . Sosialisasi sangat penting untuk memberikan pengetahuan kepada masyarakat tentang kelebihan dan keunggulan perbankan, sehingga masyarakat mengetahui, memahami dan memilh bank yang tepat sesuai dengan kebutuhannya.

b. Pengaruh Pelayanan Tehadap Minat Menabung

Istilah layanan dapat dipresepsikan berbeda-beda dalam konteks yang berlainan. Setidaknya konsep jasa mengacu pada beberapa lingkup definisi utama: industri, output atau penawaran, proses dan sistem kendati keanekaragamaan perspektif ini bisa menimbulkan kerancauan, implikasi strategi adalah bahwa komponen jasa atau pelayanan memainkan peran strategi dalam setiap bisnis.

Menurut Kotler (2002) pelayanan adalah setiap tindakan atau kegiatan yang dapat ditawarkan oleh suatu pihak kepada pihak lain, yang pada dasarnya tidak berwujud dan tidak mengakibatkan kepemilikan apapun. Pelayanan merupakan perilaku produsen dalam rangka memenuhi kebutuhan dan keinginan konsumen demi tercapainya kepuasan pada konsumen itu sendiri. Kotler juga mengatakan bahwa perilaku tersebut. dapat terjadi pada saat, sebelum dan sesudah terjadinya transaksi.

Dunia perbankan senantiasa tidak terlepas pada masalah persaingan, baik itu masalah rate/margin maupun masalah pelayanan. Dari hasil survei langsung membuktikan bahwa kualitas dari pelayanan merupakan hal yang paling dipertimbangkan masyarakat dalam memilih bergabung dengan suatu bank, sehingga sangat perlu melakukan pelayanan yang terbaik kepada nasabah agar banyak masyarakat yang mau bertransaksi.

Penilaian nasabah terhadap jasa perbankan berkaitan dengan tingkat subjektivitas, aspirasi, emosi kepuasaan, keengganan dan suasana hati. Setidaknya ada beberapa aspek yang perlu diperhatikan oleh bank yang mampu mengarahkan operasional bank pada kualitas pelayanan jasa yang baik. Diantaranya yang paling penting adalah akses. Akses ini berhubungan dengan letak bank yang strategis, pasar, sasaran, serta kemampuan yang mampu memberikan pelayanan yang cepat. (Hasan 2010).

c. Pengaruh Lokasi Terhadap Minat Menabung

Lokasi adalah letak atau toko pengecer pada daerah yang strategis sehingga dapat 
memaksimumkan laba (Basu Swasta dan Irawan dalam Rusdiana, 2014). Menurut Kasmir (2013) yaitu tempat melayani konsumen, dapat pula diartikan sebagai tempat untuk memajang barang-barang dagangannya. Pertimbangan dalam memilih letak lokasi yaitu berdasarkan jenis usaha yang akan dilakukan, keterdekatan dengan pasar / konsumen, kemudahan sarana dan prasarana, kemudahan untuk melakukan ekspansi, dekat dengan pusat pemerintahan, dan tersedianya sumber daya yang lain.

Kesimpulan bahwa lokasi adalah tempat menjalankan aktivitas yang melayani konsumen, aktivitas produksi, aktivitas penyimpanan, ataupun untuk mengendalikan kegiatan perusahaan secara keseluruhan dalam memaksimalkan laba. Menentukan lokasi merupakan keputusan penting dalam bisnis yang bertujuan untuk mewujudkan pelanggan agar datang ke tempat tersebut dalam pemenuhan kebutuhannya. Lokasi mempunyai fungsi yang strategis karena dapat ikut menentukan tercapainya tujuan badan usaha. Lokasi yang tepat dalam mendirikan suatu usaha adalah salah satu hal yang sangat menentukan keuntungan bagi perusahaan, pengusaha akan selalu mencari lokasi yang strategis, yang mudah dilihat dan dijangkau oleh konsumen. Lokasi yang tepat adalah di tempat dengan potensi pasar yang besar.

\section{Metode Penelitian}

Metode penelitian yang digunakan adalah penelitian deskriptif. Menurut Pasolong (2013), deskriptif merupakan penelitian yang mendeskripsikan apa yang terjadi pada saat melakukan penelitian. Didalamnya terdapat upaya mendeskripsikan, mencatat, menganalisa, dan menginterpretasikan kondisi-kondisi yang sekarang terjadi atau ada. penelitian ini menggunakan teknik pengumpulan data sebagai berikut :

1. Teknik Komunikasi Langsung, yaitu usaha untuk menggali keterangan yang lebih dalam dari sebuah kajian dan sumber yang relevan berupa pendapat, kesan, pengalaman, pikiran dan sebagainya. Teknik komunikasi langsung yang digunakan adalah wawancara dengan narasumber yang dianggap mengetahui permasalahan yang diangkat.

2. Teknik Komunikasi Tidak Langsung, yaitu usaha untuk menggali keterangan yang lebih dalam dari sebuah kajian dari sumber yang relevan berupa angket atau kuesioner.

3. Teknik Studi Dokumenter, yaitu catatan kejadian yang sudah lampau yang dinyatakan dalam bentuk-bentuk arsip, dokumen-dokumen, buku-buku, dan jurnal yang ada kaitannya dengan masalah yang diteliti.

Sementara alat pengumpulan data yang digunakan dalam penelitian ini yaitu :

1. Pedoman Wawancara

Yaitu alat yang digunakan dalam pengumpulan data dengan melakukan wawancara langsung atau tatap muka.

2. Angket atau Kuesioner

Yaitu alat yang digunakan dalam pengumpulan data dengan memberikan sejumlah pertanyaan tertulis kepada responden.

3. Dokumen

Yaitu alat yang digunakan dengan pengumpulan data dengan mengumpulkan dokumendokumen.

Pengelolaan data penelitian ini digunakan data analisis deskriptif yang bersifat kuantitatif, yaitu dengan cara mengelompokkan jawaban dari kuesioner menurut kriteria yang ada dan hasil masing-masing jawaban. Untuk mencari rata-rata dari setiap jawaban responden juga mempermudah penelitian hasil dari rata-rata tersebut. Menurut Bilson Simamora (2012) data yang diperoleh dianalisis dengan menggunakan nilai rata-rata untuk mengetahui penilaian responden.

Untuk mengetahui kriteria pengelompokan antar masing-masing tingkatan setelah jumlah skor penilaian dijumlahkan dan dirata-ratakan. Selanjutnya adalah mengukur skor 
jawaban responden atas pertanyaan diperoleh rentang skor dengan cara kontinum kedalam 5 kategori yaitu sangat baik, baik, cukup baik, tidak baik, dan sangat tidak baik. Skala prestasi kontinum rentang skor dapat dihitung dengan rumus sebagai berikut :

Keterangan :

$$
\mathrm{Rs}=\frac{m-n}{b}
$$

$$
\begin{array}{ll}
\mathrm{m} & =\text { skor tertinggi didalam pengukuran } \\
\mathrm{n} & =\text { skor terendah dalam pengukuran } \\
\mathrm{b} & =\text { banyak kelas yang dibentuk }
\end{array}
$$

Dengan rumus diatas, maka rentang skala dihitung sebagai berikut :

$$
\text { Rs }=\frac{5-1}{5}=0,8
$$

Skor penilaian berkisar dari angka satu sampai angka lima dengan rentang nilai 0,8 rentang penilaian dan tingkat kepuasan pelanggan terhadap pelayanan dari angka satu sampai dengan angka lima maka diperoleh seperti dibawah ini :

Tabel 3. Rentang Skor

\begin{tabular}{|l|c|}
\hline \multicolumn{1}{|c|}{ Keterangan } & Bobot \\
\hline Sangat Setuju & $4.25-5.00$ \\
Setuju & $3.40-4.19$ \\
Netral & $2.60-3.39$ \\
Tidak Setuju & $1.80-2.59$ \\
Sangat Tidak Setuju & $1.00-1.79$ \\
\hline
\end{tabular}

\section{HASIL PENELITIAN}

1. Tanggapan Responden Tentang "Informasi tentang PT. BPR Prima Multi Makmur yang dapat menarik minat masyarakat menabung masih kurang”.

Dalam menganalisis tentang minat menabung, hal pertama yang dapat digunakan dalam menilai nasabah mempunyai minat menabung adalah apakah informasi tentang PT. BPR Prima Multi Makmur dapat menarik minat masyarakat menabung. . Hasil tanggapan responden mengenai pernyataan "Informasi tentang PT. BPR Prima Multi Makmur yang

\begin{tabular}{|c|c|c|c|c|}
\hline Keterangan & Bobot & Responden & $\begin{array}{c}\text { Persentase } \\
(\%)\end{array}$ & Total Skor \\
\hline Sangat Setuju & 5 & 1 & 3,33 & 5 \\
\hline Setuju & 4 & 7 & 23,33 & 28 \\
\hline Netral & 3 & 7 & 23,33 & 27 \\
\hline Tidak Setuju & 2 & 11 & 36,67 & 22 \\
\hline Sangat Tidak Setuju & 1 & 4 & 13,34 & 4 \\
\hline Jumlah & & 30 & 100,00 & 86 \\
\hline \multicolumn{4}{|c|}{ Rata-rata } & 2,87 \\
\hline
\end{tabular}
dapat menarik minat masyarakat menabung masih kurang" dapat dilihat pada Tabel 3.6 di bawah ini:

Tabel 4. Tanggapan Responden Mengenai Informasi Tentang PT. BPR Prima Multi Makmur Dapat Menarik Minat Masyarakat Menabung Masih Kurang

Sumber :Data Olahan, 2021

Berdasarkan Tabel 4 diketahui bahwa dari 30 responden, terdapat sebanyak 1 responden atau 3,33 persen menyatakan sangat setuju, sebanyak 7 responden atau 23,33 persen menyatakan setuju, sebanyak 7 responden atau 23,33 persen menyatakan netral,sebanyak 11 responden atau 36,67 persen menyatakan tidak setuju dan sebanyak 4 responden atau 13.34 
persen menyatakan sangat tidak setuju mengenai "Informasi Tentang BPR Prima Multi Makmur Dapat Menarik Minat Masyarakat Menabung Masih Kurang”.

Dari Tabel 4 juga dapat dilihat rata-rata tanggapan responden mengenai "Informasi Tentang BPR Prima Multi Makmur Dapat Menarik Minat Masyarakat Menabung Masih Kurang" adalah sebesar 2,87 dan angka tersebut berada pada rentang 2.60 - 3.39 masuk dalam kategori "netral", .Kondisi ini menggambarkan informasi tentang PT Bpr Prima Multi Makmur dapat menarik minat masyarakat menabung masih kurang berada pada nilai netral, sehingga tidak menunjukkan pengaruh yang signifikan terhadap minat menabung nasabah.

2. Tanggapan Responden "Saya tidak menabung di PT. BPR Prima Multi Makmur karena belum terlalu mengetahui tentang konsep dan mekanismenya “

Berdasarkan pengertian minat beli yakni keinginan atau dorongan yang timbul dari diri seseorang untuk membeli barang dan jasa dalam rangka pemenuhan kebutuhannya, maka dapat disimpulkan minat menabung disini merupakan keinginan yang disertai keputusan untuk menjadi nasabah. Ini merupakan bukti bahwa konsumen yakin bahwa produk atau jasa yang mereka beli dapat memenuhi keinginan dan kebutuhan mereka. Untuk mengambil keputusan dalam pembelian suatu produk, nasabah perlu mengetahui mekanisme pembelian produk tersebut. Untuk mengetahui tanggapan responden mengenai konsep dan mekanisme menabung di PT BPR Prima Multi Makmur dapat dilihat pada Tabel 3.7 berikut ini:

Tabel 5. Tanggapan Responden Saya Tidak Menabung Di PT.BPR Prima Multi Makmur Karena Belum Terlalu Mengetahui Tentang Konsep Dan Mekanismenya

\begin{tabular}{|c|c|c|c|c|}
\hline Keterangan & Bobot & Responden & Persentase & Total Skor \\
\hline Sangat Setuju & 5 & 3 & 10,00 & 15 \\
\hline Setuju & 4 & 6 & 20,00 & 24 \\
\hline Netral & 3 & 3 & 10,00 & 9 \\
\hline Tidak Setuju & 2 & 17 & 56,67 & 34 \\
\hline Sangat Tidak Setuju & 1 & 1 & 3,33 & 1 \\
\hline Jumlah & & 30 & 100,00 & 83 \\
\hline \multicolumn{4}{|c|}{ Rata-rata } & 2,77 \\
\hline
\end{tabular}

Sumber :Data Olahan, 2021

Berdasarkan Tabel 5 diketahui bahwa dari 30 responden, terdapat sebanyak 3 responden atau 10,00 persen menyatakan sangat setuju, sebanyak 6 responden atau 20,00 persen menyatakan setuju, sebanyak 3 responden atau 10,00 persen menyatakan netral, sebanyak 17 responden atau 56,67 persen menyatakan tidak setuju dan sebanyak 1 responden atau 3,33 persen menyatakan sangat tidak setuju mengenai "Saya Tidak Menabung di PT Bpr Prima Multi Makmur Karena Belum Mengetahui Konsep dan Mekanismenya".

Dari Tabel 5 juga dapat dilihat rata-rata tanggapan responden mengenai"Saya Tidak Menabung di PT Bpr Prima Multi Makmur Karena Belum Mengetahui Konsep dan Mekanismenya" adalah 2,77 berada pada rentang 2.60 - 3.39 masuk dalam kategori "netral. Kondisi ini menggambarkan pengaruh dari konsep dan mekanisme PT BPR Prima Multi Makmur dapat menarik minat masyarakat menabung masih berada pada posisi netral, sehingga tidak menunjukkan pengaruh yang signifikan terhadap minat menabung nasabah.

\section{Tanggapan Responden Mengenai "Iklan - Iklan Tentang PT. BPR Prima Multi}

Makmur Jarang Kita Temukan

Pada saat ini kemajuan teknologi sangat berperan penting dalam dunia bisnis, kemajuian teknologi sangat membantu kita dalam memasarkan barang maupun jasa. Dengan adanya teknologi kita dapat mempromosikan produk-produk yang kita hasilkan, begitu juga 
dalam dunia perbankan promosi sangat membantu kita dalam pencapaian target dan sasaran, Adapun media yang dapat dipakai dalam memasarkan produk bisa melalui iklan-iklan dikoran, televisi, FaceBook, Instagram, dan lain-lain, hal ini dapat berpengaruh pada minat menabung nasabah. Untuk mengetahui tanggapan responden mengenai "Iklan - Iklan Tentang PT. BPR Prima Multi Makmur Jarang Kita Temukan" dapat dilihat pada Tabel 3.8 berikut ini :

Tabel 6. Tanggapan Responden Mengenai Iklan-Iklan Tentang PT. BPR Prima Multi Makmur Jarang Ditemukan

\begin{tabular}{|l|c|c|c|c|}
\hline \multicolumn{1}{|c|}{ Keterangan } & Bobot & Responden & Persentase & Total Skor \\
\hline Sangat Setuju & 5 & 5 & 16,67 & 25 \\
\hline Setuju & 4 & 14 & 46,67 & 56 \\
\hline Netral & 3 & 6 & 20,00 & 18 \\
\hline Tidak Setuju & 2 & 3 & 10,00 & 6 \\
\hline Sangat Tidak Setuju & 1 & 2 & 6,66 & 2 \\
\hline \multicolumn{2}{|r}{ Jumlah } & 30 & 100,00 & 107 \\
\hline \multicolumn{2}{|l|}{ Rata-rata } & 3,57 \\
\hline
\end{tabular}

Sumber :Data Olahan, 2021

Berdasarkan Tabel 6 diketahui bahwa dari 30 responden, terdapat sebanyak 5 responden atau 16,67 persen menyatakan sangat setuju, sebanyak 14 responden atau 46,67 persen menyatakan setuju, sebanyak 6 responden atau 20,00 persen menyatakan netral, sebanyak 3 responden atau 10,00 persen menyatakan tidak setuju dan sebanyak 2 responden atau 6,66 persen menyatakan sangat tidak setuju mengenai "Iklan - Iklan Tentang PT. BPR Prima Multi Makmur Jarang Kita Temukan"

Dari Tabel 6 juga dapat dilihat rata-rata tanggapan responden mengenai"Iklan-Iklan Tentang BPR Prima Multi Makmur Jarang Ditenukan" adalah 3,57 berada pada rentang 3.40 4.19 masuk dalam kategori "setuju". Kondisi ini menggambarkan pengaruh iklan iklan sebagai media promosi berpengaruh terhadap minat menabung nasabah., Oleh sebab itu dengan adanya tanggapan responden diharapkan PT BPR Prima Multi Makmur dapat meningkatkan kinerja produknya melalui iklan-iklan sehingga dapat diketahui oleh masyarakat dengan tujuan dapat meningkatkan minat menabung masyarakat.

\section{SIMPULAN DAN SARAN}

Berdasarkan hasil analisis dan pembahasan yang telah dikemukakan pada bab sebelumnya, mengenai Minat Menabung Nasabah PT BPR Prima Multi Makmur, maka dapat ditarik kesimpulan, berdasarkan hasil analisis menggunakan skala likert pada tiga puluh kuesioner untuk tanggapan responden yang telah disebarkan, peneliti menetapkan indikator pmendapatkan nilai rata-rata sebesar 3.07 masuk dalam kategori "Netral".

Berdasarkan hasil penelitian yang diperoleh dari data-data di lapangan, pada dasarnya penelitian ini berjalan baik. Namun peneliti ingin mengemukakan beberapa saran yang semoga bermanfaat bagi pihak PT BPR Prima Multi Makmur, pembaca maupun peneliti selanjutnya. Adapun saran yang dapat peneliti sampaikan adalah sebagai berikut :

1. PT. BPR Prima Multi Makmur harus mempertahankan dan memberikan kualitas layanan yang terbaik kepada semua nasabah, tanpa kecuali, sehingga minat nasabah untuk menabung akan meningkat, dan tujuan perusahaan dapat tercapai

2. BPR Prima Multi Makmur hendaklah meningkatkan promosi dengan menggunakan teknologi sebagai media promosi dalam memberikan informasi tentang produk dan layanan, sehingga dapat menarik minat menabung masyarakat.

3. Para penelitian selanjutnya diharapkan dapat membahas faktor-faktor lain yang dapat 
mempengaruhi minat menabung dan mengembangkan ruang lingkup penelitian dengan mencari permasalahan lainnya untuk diuji

\section{Referensi}

Abdallah, M., \& Lubis, I. (2015). Analisis Minat Menabung Pada Bank Syariah di kalangan Siswa SMA di Kota Medan (Studi Kasus: Siswa Madrasah Aliyah Negeri). Jurnal ekonomi dan keuangan, 3(6), 14859.

Alfian, Lain. (1994). Pengantar Ekonomi Mikro. Jakarta: Karunika.

Anto Dajat. (2000). Pengantar Metode Statistik. Jilid II. Jakarta: LP3ES.

Damayanti, Maysaroh. (2014). Faktor-faktor yang Mempengaruhi Keputusan Nasabah dalam Memilih Bank Syariah, UIN Sunan Kalijaga Yogyakarta. Jurnal Ekonomi dan Bisnis, 5(7).

Dewi, Ayu Nurtika. (2015). Analisis Faktor - Faktor yang mempengaruhi minat masyarakat untuk menabung. Jurnal EMBA, 18(23).

Kasmir. (1998). Bank dan Lembaga Keuangan Lainnya. Jakarta: Raja Grafindo Persada.

Kasmir. (2008). Bank dan Lembaga Keuangan Lainnya. Jakarta: PT.Raja Grafindo Persada

Kotler, et al. (2008). Prinsip - Prinsip Pemasaran Edisi 12 Jilid 1. Jakarta: Erlangga.

Kotler, et al. (2009). Prinsip - Prinsip Pemasaran Edisi 12 Jilid 2. Jakarta: Erlangga.

Kotler, Philip \& Amstrong, G. (2008). Prinsip-Prinsip Manajemen Pemasaran edisi 12. Jakarta: PT. Indeks

Kuncoro, Mudardjat. 2003. Metode Riset Untuk Bisnis dan Ekonomi. Jakarta: Erlangga.

Lubis, Irsyad. (2010). Bank dan Lembaga Keuangan Lain. Medan: USU Press.

Minarti. (2003). Analisa Pengaruh Pendapat dan Tingkat Bunga Terhadap Hasrat Menabung Pada Bank Negara Indonesia Cabang Bukittinggi. Bukittinggi

Sadono Sukirno. (1994). Teori Pengantar Ekonomi Makro Edisi ketiga. Jakarta: Karunika.

Soediyono, Reksorayitno. (1992). Prinsip-Prinsip Dasar Manajemen Bank Umum; Penerapannya di Indonesia. Edisi Kesatu. Yogyakarta: BPFE.

Soediyono. (1985). Ekonomi Makro Pengantar Analisa Pendapat Nasional Edisi Keempat. Yogyakarta: Liberty.

Soemitra, Andri. (2009). Bank \& lembaga keuangan syariah, cetakan kedua. Jakarta: Prenada Media. 